\title{
Spomeniki padlim v prvi svetovni vojni na Kočevskem v luči povojnih razmer
}

ANJA MORIC

Velika vojna ni prizadela le držav oziroma območij, kjer so bitke neposredno potekale, temveč tudi tako imenovane kraje v zaledju, med katere sodi tudi območje širše Kočevske na jugovzhodu Slovenije. ${ }^{\mathbf{1}}$ Redko obljudeno kočevsko pokrajino so po dognanju jezikoslovcev v 14. stoletju večinoma poselili kolonisti z ortenburških posesti na zgornjem Koroškem in vzhodnem Tirolskem (Petschauer 1984: 87). Začetni fazi kolonizacije naj bi sledila priselitev 300 uporniških družin iz

1 Izraz Kočevska uporabljam za poimenovanje nekdanjega večjezikovnega območja na Kočevskem, kjer je pred drugo svetovno vojno prevladovala raba kočevarščine, govorilo pa se je tudi nemški in slovenski ter v manjšem obsegu celo hrvaški (priseljenci s Hrvaške) in romski jezik (Romi). Za geografski obseg območja glej Ferenc (2005: 19-20). 
Frankovske in Turingije (Grothe 1931: 33), del priseljencev pa naj bi prišel iz drugih slovenskih regij - Stari Trg, Lož, Cerknica, Idrija (Petschauer 1984: 87-8). Možno je, da so bili med kolonisti v manjšem številu tudi koroški Slovenci (Simonič 1971: 9). ${ }^{2}$ Zaradi priselitve iz različnih krajev, kjer se je govorilo različne jezike in narečja, kot tudi zaradi stikov z okoliškim prebivalstvom, se je na Kočevskem razvilo zanimivo mešano jezikovno območje, kjer je 600 let - vse do preselitve večine prebivalstva v nemški rajh v letih 1941/42 - prevladovala raba Kočevarščine ${ }^{3}$ - srednjeveške nemščine $s$ primesmi slovenščine (glej Schröer 1869; Hauffen 1895; Tschinkel 2004 itd.). Nacionalistične ideje, zlasti predstava o $\gg$ nemških jezikovnih otokih «, ki so se v devetnajstem in dvajsetem stoletju razširile po Evropi, za raznolikost, kot jo je bilo moč najti na Kočevskem (gl. Moric 2020) pa tudi v drugih mešanih regijah avstro-ogrske monarhije (gl. Judson 2006; Zahra 2008), niso bile odprte, saj se niso osredotočale na podobnosti in sobivanje, pač pa na razlike in meje (gl. Barth 1998) med etničnimi skupinami. Odnosi med kočevskimi »Nemci« in »Slovenci« so se na prelomu devetnajstega in dvajsetega stoletja vse bolj radikalizirali, narodnostno razlikovanje pa se je še utrdilo po koncu prve svetovne vojne oziroma z določitvijo novih državnih meja.

Ob zaukazani mobilizaciji, 26. julija 1914, se podobno kot drugi prebivalci Avstro-Ogrske (glej npr. Cornwall 2015) tudi Kočevarji niso zavedali resnosti situacije. Gottscheer Kalender je poročal, da so fantje in možje iz fare Mozelj na bojišča odhajali » z entuziazmom, humorjem in brezskrbno, kot bi šli na orožne vaje v času miru « (Erker 1930a: 53). Pričakovali so, da se bodo vrnili še pred božičem, dejansko pa se marsikateri izmed njih ni nikoli več vrnil domov. Odšlo je okoli 1600 mož (Trdan 1996: 97). Večina je bila dodeljena v 3. korpus, v 17. pehotni polk (Nepodpisano 1916: 184) na tako imenovano vzhodno oziroma rusko fronto (v Galiciji); borili pa so se tudi na soški in tirolski fronti. V prvem letu vojne, do jeseni 1915, je bil kar vsak štirinajsti kočevarski vojak odlikovan ali pohvaljen za svojo hrabrost (Trdan 1996: 97). Natančnega podatka o tem, koliko kočevarskih mož je v vojni izgubilo življenje, nimamo. Večina padlih je pokopana na tujem, v bližini bojišč.

Čeprav je zaradi vojne smrt potrkala na vrata marsikatere kočevarske hiše, so Kočevsko bolj kot vojna sama zaznamovale razmere, ki kolonizacija dolg proces, ki je trajal vse do konca štirinajstega stoletja. Več o rabi kočevarščine med sodobnimi Kočevarji v Sloveniji, Avstriji, Nemčiji, ZDA in Kanadi v Moric (2010). 
so nastopile po njej. S koncem vojne je do izraza prišla dejanska večnacionalnost razpadlega Avstro-ogrskega cesarstva. Dejstvo, da je bilo na njegovem ozemlju praktično nemogoče osnovati etnično čiste nacionalne države, $\mathrm{k}$ čemur so stremele države naslednice, je zaradi hkratnega razcveta nacionalističnih gibanj podžgalo številna trenja, zlasti na območjih z jezikovno mešanim prebivalstvom, med drugim tudi na Kočevskem, kjer je prišlo do nasprotij med tamkajšnjimi »Nemci « in »Slovenci«. Medtem ko se je Slovencem uresničila želja po emancipaciji v skupni državi Jugoslovanov, so kočevski Nemci oblikovanje novonastale nacionalne tvorbe doživljali kot zmanjšanje svojih pravic. Nove razmere so se zrcalile v željah po nastanku novih oziroma drugačnih političnih tvorb, žalovanju za starim sistemom, zahtevah po ohranitvi pravic nemške manjšine, ne nazadnje pa tudi v nastajanju novih »krajev spomina « (Nora 1989), sporočilnosti spomenikov prvi svetovni vojni in vsebini slovesnosti, ki so jih spremljale.

Prispevek v prvem delu osvetljuje razmere na Kočevskem ob koncu prve svetovne vojne, predvsem prizadevanja kočevskih Nemcev za politično samostojnost $\mathrm{v}$ lastni državi in pridobitev manjšinskih pravic. $V$ drugem delu pa predstavi v luči povojnih razmer nastale spomenike v prvi svetovni vojni padlim vojakom in njihovo (politično) sporočilnost. Izhajam predvsem iz analize objav v periodičnih publikacijah, ki so na kočevskem izhajale med svetovnima vojnama, in sicer Gottscheer Bote (1904-1919), Gottscheer Zeitung (1919-1941) in Gottscheer Kalender (1921-1941), uporabim pa tudi nekatere podatke, ki sem jih zbrala tekom raziskave Ohranjanje identitete Kočevarjev, izvedene med Kočevarji v Sloveniji, Avstriji, Nemčiji, ZDA in Kanadi od leta 2007 do 2015 (Moric 2016).

\section{PRELOMNO LETO 1918 - »ZAČETEK KONCA KOČEVSKE DEŽELE«}

Veselje in optimizem, ki sta spremljala začetek vojne, je čez štiri leta nadomestilo razočaranje. Kako tragično je bil izid vojne sprejet na Kočevskem, slikovito opiše časopis Gottscheer Bote, izdan 19. novembra 1918:

Mi, Kočevarji, ki smo se vedno z ljubeznijo in naklonjenostjo obračali na častitljivo cesarsko državo Avstrijo, smo njen razpad doživeli z najbolj bolečimi občutki. Sramota in ponižanje, ki sta se zdaj zgodila velikemu nemškemu narodu, sta nam v oči priklicala solze grenke bolečine. Težko je prenašati takšno usodo in ne obupati nad grozno nesrečo, ki je prizadela nemški narod. Kljub temu pa si ne pustimo 
vzeti upanja, da bo po sedanji Golgoti za nemški narod prišel dan vstajenja. V teh težkih dneh se nam, Kočevarjem, v tem vrtincu dogodkov zastavlja tesnobno vprašanje: kako bo z našo prihodnjo usodo? Prihodnost mnogi od nas vidijo v najtemnejših barvah. Tu in tam se širi obup. (Nepodpisano 1918g: 169)

Na nezadovoljstvo kočevskih Nemcev s političnimi razmerami ob koncu vojne in nastajajočo novo državo, kažejo njihova prizadevanja za priključitev k Avstriji oziroma za neodvisnost Kočevske. Še preden se je prva svetovna vojna končala in so se že kazali realni obrisi novih nacionalnih držav, med njimi jugoslovanske, so se organizirali kočevarski duhovniki. Ti so 23. januarja 1918 na zasedanju v Kočevju sprejeli resolucijo, v kateri so izrazili zahtevo po avtonomnem območju s pravico do samoodločbe, pri čemer so se sklicevali predvsem na katolištvo. Zapisali so, da je nadaljnji obstoj močne Avstrije »v interesu katoliške vere « in da bi, ker je Avstro-Ogrska svetovna katoliška velesila, oslabitev monarhije zaradi delitve na manjše nacionalne države » pomenila tudi oslabitev katolicizma « (Nepodpisano 1918a: 17).

Če je treba ali zaželeno, da se ustava naše države spremeni in narodi dobijo več pravic in večjo stopnjo samoodločbe, potem bi to nujno moralo potekati v skupni avstrijski državi, ne pa z njenim brezobzirnim razkosanjem v množico za življenje komaj sposobnih, med seboj komaj povezanih držav. (Nepodpisano 1918a: 18)

Emancipatorna prizadevanja slovenskih dežel so označili za utopična in nedosegljiva, ob tem pa izrazili skrb, da bi v morebitni neodvisni jugoslovanski državi sčasoma prevladala srbofilija in z njo težnje po ločeni nacionalni dinastiji s pravoslavnimi tendencami. Navedli so, da tudi kulturni razlogi in premisleki o materialni blaginji ljudstva govorijo proti vključitvi Kranjske v jugoslovansko državo, saj so bili Kranjci od nekdaj del Zahodne in Srednje Evrope. Kar bi sicer pomenilo, da bi bili s priključitvijo $\mathrm{k}$ jugoslovanski državi nasilno iztrgani iz svojega naravnega, geografskega in zgodovinskega okvira ter vstopili v tujo kulturo. Ločitev Kranjske od bogatejših avstrijskih dežel in združitev z revnejšimi državami bi - po mnenju avtorjev resolucije - verjetno poslabšali finančni položaj Kranjske. Kljub občasnim zagotovilom o zaščiti in pravičnem upoštevanju pravic narodnih manjšin $\mathrm{v}$ bodoči neodvisni jugoslovanski državi, so menili, da bi nemške fare in občine na Kranjskem čakali težki časi kot tudi brezupen boj za ohranitev njihovega etničnega obstoja. Izrekli so se proti »vključitvi nemškega kočevarskega območja v želeno jugoslovansko državo «, in se pri tem sklicevali na 600-letno prisotnost in ohranjanje kulture na Kočevskem, 
ki jim dajeta neizpodbitno pravico do ohranjanja in upoštevanja njihove nemške narave in nemškega značaja: »Kočevarji želijo biti brez kakršnegakoli nacionalnega zatiranja, stiske in ogroženosti, zato zahtevajo konsolidacijo v avtonomnem območju s pravico do samoodločbe « (Nepodpisano 1918a: 19). Duhovniki so izjavo naslovili tudi na škofa Antona Bonaventuro Jegliča, ki se je z njihovimi zahtevami za ohranitev pravic strinjal, kljub temu, da se, kot navaja $\mathrm{v}$ dnevniškem zapisu »od Cerkvene strani še niso nikdar kršile« (Jeglič 2015: 745). Odločil pa se je, da na dopis ne bo odgovoril.

Slutnja prihajajočih sprememb ni povzročala sivih las le kočevarskim duhovnikom. Na seji, 28. marca 1918, se je proti potencialni jugoslovanski državi izrekel tudi kočevski mestni svet (Nepodpisano 1918b: 50). Meseca maja 1918, pa sta kočevsko delegacijo, v kateri so se predstavnikom duhovščine pridružili še voditelji lokalnih skupnosti, ${ }^{4}$ na isti dan kot Korošce, nemške in slovenske župane ter občinske zastopnike iz Spodnje Štajerske, Spodnje Kranjske in Trsta, sprejela cesar Karl I. in ministrski predsednik dr. Seidler von Feuchtanegg. Kočevski dekan Ferdinand Erker je tudi njima posredoval željo po nadaljnjem obstoju velike Avstrije, župan Alois Loy pa je cesarja prosil, naj »nemški jezikovni otok « na Kočevskem ljubeznivo vzame pod svojo zaščito, saj so jugoslovanske težnje resna grožnja obstoju monarhije in nemški narodnosti Kočevarjev (Nepodpisano 1918c: 82).

Ko je postalo jasno, da je Avstro-Ogrska vojno izgubila, so Kočevarji, ki na združitev z Avstrijo več niso mogli resno računati, upanje vse bolj polagali na idejo ameriškega predsednika Woodrowa Willsona o samoodločbi narodov. ${ }^{5}$ Oktobra 1918 je v resoluciji željo po priključitvi Kočevske Nemški Avstriji oziroma, če ta ne bi bila mogoča, ustanovitev neodvisne republike izrazil tudi Nemški narodni svet za Kočevsko (Deutsche Volksrat für Gottschee) (Svoljšak 1995: 105), ki ga je vodil župan Alois Loy, in je imel namen varovati »kočevarski narodni interes «(Arko s. d.). Morebitne pomisleke glede velikosti predlagane državne tvorbe so avtorji resolucije vnaprej zavrnili z navedbami o številčnosti Kočevarjev, samostojno upravo Kočevske v različnih zgodovinskih obdobjih in primerjavo z Monakom in Lihtenštajnom:

Kočevsko delegacijo so sestavljali: kočevski dekan Ferdinand Erker, cesarski svetnik in župan Kočevja Alois Loy, kočevskoreški župnik Josef Kraker, vodja občine Željne Matthias Michitsch ter vodja občine Livold Josef Ostermann (Nepodpisano 1918c: 81). Willsona, katerega je ta še julija 1918 ostro kritiziral (Nepodpisano 1918d: 1056), nedolgo po koncu vojne pa je že polagal upe na »njegov občutek za pravičnost « (Nepodpisano 1919d: 25). 
Območje Kočevske s svojo nemškostjo ni zgolj nepomemben, majhen ljudski drobec. Že 600 let deželico naseljuje 18.000 avtohtonih Nemcev - vključno z izseljenci v Ameriki 24.000 - v 171 vaseh, 25 političnih skupnostih, z več kot 30 ljudskimi šolami, 17 župnijami in v popolnoma zaprti skupnosti. Kočevska je bila nekoč grofija, od leta 1791 pa je vojvodina. Na Kranjskem je od nekdaj tvorila poseben del, ki ga je oblikovalo lastno nacionalno življenje. $\mathrm{V}$ času francoske vladavine na Kranjskem je bila Kočevska samostojen kanton. Območje Kočevske s svojo prostorsko razsežnostjo več kot 700 kvadratnih kilometrov nekajkrat presega velikost suverenih republik Monako in San Marino ter Kneževine Lihtenštajn, tako po površini kot po številu prebivalstva. V vsakem primeru bi bila Kočevska sposobna preživeti. (Nepodpisano 1918e: 154)

Enake argumente so predstavili čez mesec dni, novembra 1918. Tedaj je dvajset kočevskih občin poslalo prošnjo narodni vladi v Ljubljani, da bi se do odločitve mirovne konference narodne pravice Nemcev na Kočevskem ohranile na enakem nivoju kot pred vojno, da bi se v uradih še naprej uporabljal (tudi) nemški jezik, na podlagi Wilsonovih točk pa so zahtevali še pravico do samoodločbe in samouprave (Nepodpisano 1918h: 177; Svoljšak 1995: 104).

Spremembe in negotovost, ki jih je prinašal konec vojne, so vznemirjale tudi druge prebivalce monarhije. Ideje o neodvisnih republikah na podlagi pravice narodov do samoodločbe so se pojavljale širom propadle države. Češki Nemci so, na primer, podobno zahtevo po samoodločbi na podlagi Wilsonovih točk predstavili kmalu po nastanku Češkoslovaške, 28. oktobra 1918, in samooklicali državico Nemško Češko (gl. Judson 2018: 480), ki pa je bila kratkega roka trajanja. ${ }^{6}$ Tudi na slovenskih tleh je konec leta 1918 in v začetku 1919 prišlo do poskusa ustanovitev samostojnih državnih tvorb, a so zaradi posredovanja vojske propadle, preden so uspele dejansko zaživeti. Kandijska republika na Dolenjskem (ustanovljena 27. decembra 1918) je, na primer, obstajala štiri, Viniška republika v Beli Krajini (ustanovljena 21. aprila 1919) pet, Murska republika v Prekmurju (ustanovljena 29. maja 1919) pa šest dni. Vzniknili so tudi spontani upori kmetov, rudarjev in vojakov, na primer v Moravčah, Posavju, Kostanjevici, Halozah, Trbovljah in Mariboru (Weiss 2010: 36), ki so izražali »svoje nestrinjanje z vladajočimi političnimi, družbenimi in ekonomskimi razmerami « (Weiss 2010: 48).

Neposrednih dokazov o tem, da bi Kočevarji neodvisno republiko dejansko razglasili, ni, vendar so govoricam o njenem oklicu 
sledile preiskave in aretacije kočevarskih voditeljev (Biber 1966: 31). Ideji o avtonomiji Kočevske so oktobra 1918 v spomenici Narodnemu svetu v Ljubljani oziroma Narodnemu vijeću v Zagrebu nasprotovali kočevski Slovenci (Biber 1963: 27), časopis Slovenec pa je objavil serijo pisem, v katerih je pisec, kočevski domačin, nanizal vrsto pikrih argumentov proti ustanovitvi kočevske državice (Nepodpisano 1918i: 1; 1918j: 2; 1918l: 5-6; 1918m: 5; 1919b: 6; 1919c: 2). ${ }^{7}$

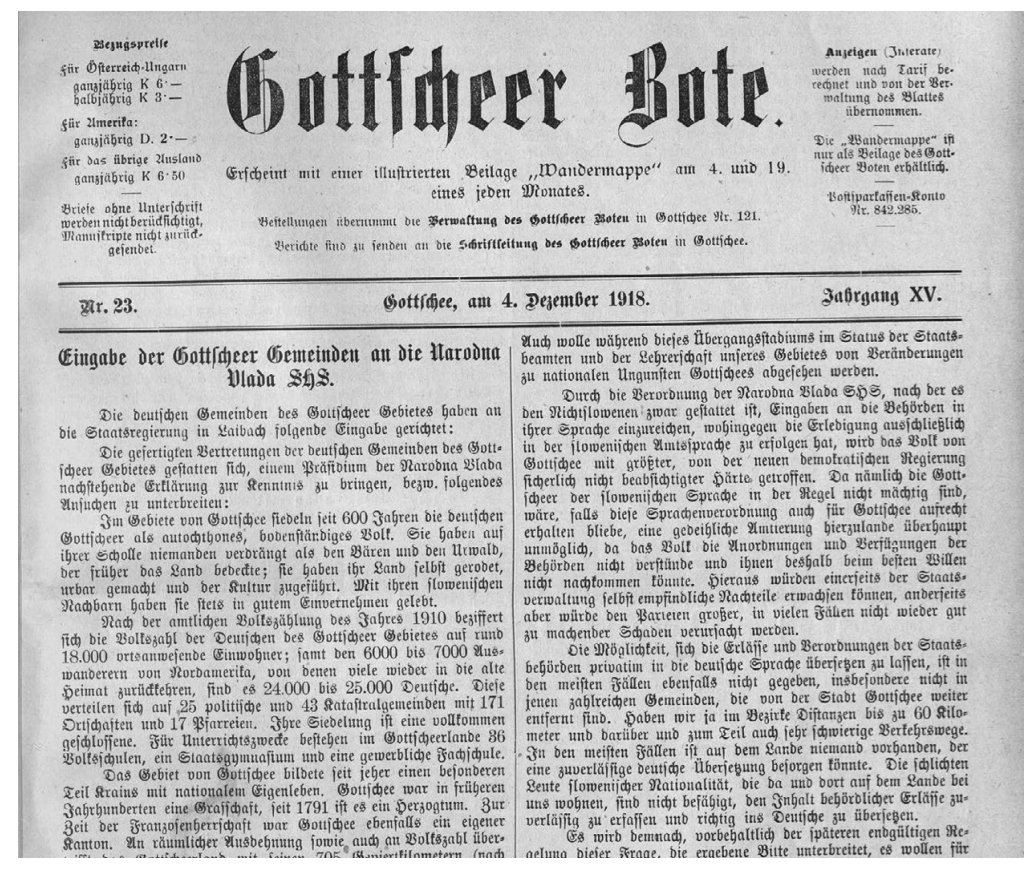

Slika 1: Prošnja narodni vladi, objavljena v časopisu Gottscheer Bote 4. decembra 1918.

Kočevarska prizadevanja niso obrodila sadu. Rodila se je nova ideja o rešitvi kočevarskega vprašanja. Prvega marca 1919 je Nemški narodni svet za Kočevsko ameriški komisiji na Dunaju izročil memorandum, ${ }^{\mathbf{8}} \mathrm{v}$ katerem je spet izrazil zahtevo po ustanovitvi neodvisne države Kočevske, a tokrat pod protektoratom katerekoli nenemške velesile ali ZDA (Svoljšak 1995: 103).

Nemški narodni svet za Kočevsko je tudi mnenja, da bi samostojna država (republika) Kočevska lahko najbolje zagotovila narodno in kulturno eksistenco Kočevarjev. Glede državnopravne podrejenosti pisal tudi dunajski Fremden-Blatt (Nepodpisano 1919e: 1; 1919f: 2). 
naj ne bi pripadala niti Jugoslaviji niti Nemški Avstriji (Nemčiji), po mnenju strokovnjakov pa bi bila sposobna za samostojno življenje. Njen državni status bi moral biti mednarodno priznan, podrejen varstvu neke nenemške velesile, ker bi bila sicer pod močnim pritiskom sosednje Jugoslavije, ki bi si jo podredila. (Svoljšak 1995: 105)

Želeli so, da bi Kočevska tudi v prihodnje ostala nemška, obliko, v kateri naj bi se to zgodilo (samostojna država ali kanton po švicarskem zgledu), pa so prepustili odločitvi mirovne konference. Če mnenje Narodnega sveta za Kočevsko ne bi zadostovalo, so predlagali rešitev problema s plebiscitom (Svoljšak 1995: 105; Ferenc 2005: 61). Kdo je bil pobudnik ideje o neodvisni republiki pod ameriškim protektoratom, ni znano, vendar je o njej 18. marca 1919 poročal tudi časopis The New York Times. Iz objave izvemo, da so se v podporo ideji zbrali Kočevarji iz Brooklyna in na predsednika ZDA naslovili prošnjo, naj na mirovni konferenci izvede zaslišanje v zvezi z neodvisnostjo Kočevske (Nepodpisano 1919g). Podatek ni presenetljiv, saj je številčno močna kočevarska diaspora $\mathrm{v}$ ZDA vsa leta ostajala tesno povezana $\mathrm{z}$ izvorno domovino Kočevsko. V času kriz ji je pomagala s pošiljanjem denarja in materialnimi dobrinami, sodelovala pa je tudi pri njeni obnovi po vojni. ${ }^{9} \mathrm{~V}$ ozadju želje po ameriškem protektoratu je verjetno tlelo upanje, da bo predsednik Wilson prisluhnil skupini svojih državljanov in se zavzel za pravice njihovih rojakov na Kočevskem. Memorandum so Kočevarji poslali tudi italijanski vladi (Svoljšak 1995: 106) in izpostavili politične ter gospodarske koristi, ki bi jih od samostojne Kočevske imela Italija.

\section{SPREMENJEN POLOŽAJ (KOČEVSKIH) NEMCEV PO VOJNI - MANJŠINSKO VPRAŠANJE}

Omenjena prizadevanja so naletela na gluha ušesa oziroma so jim na slovenski strani ostro nasprotovali (glej Trdan 1999: 93-7; Biber 1963: 27). Obljube Antona Korošca in Janka Benkoviča o spoštovanju manjšinskih pravic, ki sta jih izrekla na zasedanju državnega zbora malo pred koncem vojne (Nepodpisano 1918e: 153), se niso izpolnile. Položaj nemške manjšine v Jugoslaviji in Sloveniji se je začel slabšati, in to kljub temu da je Kraljestvo SHS z mirovno pogodbo, ki jo je 10. oktobra 1919 v Saint Germainu sklenilo z Avstrijo, nemški manjšini 
zagotovilo minimalno manjšinsko varstvo. Zavezalo se je, da bo ščitilo manjšine, ki se rasno, versko ali jezikovno razlikujejo od večinskega prebivalstva. Podobne obveze do svojih manjšin je sprejela tudi Avstrija (Cvirn 2002: 114). Kraljestvo Srbov, Hrvatov in Slovencev, Poljska, Romunija, Grčija in Češkoslovaška so morale z zavezniki podpisati še posebno mirovno pogodbo o zaščiti narodnih manjšin, ki pa je manjšinam v Kraljestvu Srbov, Hrvatov in Slovencev zagotavljala le osebno, ne pa tudi skupinske zaščite. Na pravice manjšin sta se neposredno nanašala 8. in 9. člen te pogodbe, ki sta jim dovoljevala (na lastne stroške) ustanavljati in upravljati dobrodelne, verske in socialne ustanove, šole in druge vzgojne zavode, kjer lahko »svobodno rabijo svoj jezik in izpovedujejo svojo vero « (Komac in Zagorac 2002: 142). Kraljestvo Srbov, Hrvatov in Slovencev se je obvezalo, da bo v krajih, kjer je manjšina številčno dovolj zastopana, $v$ ljudskih šolah pouk potekal $\mathrm{v}$ jeziku manjšine, zagotovilo pa naj bi jim tudi pravico do koriščenja javnih sredstev za šolstvo, verske in dobrodelne namene (Komac in Zagorac 2002: 143). Za slovenske Nemce sta bila pomembna tudi 3. in 4. člen omenjenega dogovora, po katerih so nekdanji avstrijski, ogrski in bolgarski državljani na območjih, ki so po novem sodila v okvir novonastale nacionalne države, lahko pridobili državljanstvo Kraljestva Srbov, Hrvatov in Slovencev na podlagi domicila ali domovinske pravice, polnoletne osebe pa so tudi dobile možnost, da optirajo za vsako drugo državljanstvo, ki jim je bilo na voljo. Osebe, ki so se odločile za pravico do izbire, so morale v roku 12 mesecev prenesti svoj domicil v državo, za katero so optirale. Pri tem so lahko obdržale nepremično premoženje, ki so ga imele v Kraljestvu Srbov, Hrvatov in Slovencev, in smele odnesti svojo premično lastnino (Komac in Zagorac 2002: 141). Vendar pogodba o zaščiti narodnih manjšin ni bila vključena niti v ustavo iz leta 1921 niti v ustavo iz leta 1931, čeprav se je država obvezala, da bo člene iz te manjšinske pogodbe priznala kot temeljne zakone. Zgolj 16. člen vidovdanske ustave je manjšinam pod pogoji, ki jih določi zakon, načeloma zagotavljal pravico do šolstva $v$ maternem jeziku (Cvirn 2002: 116). Določila pogodbe so se vse do druge svetovne vojne zelo pomanjkljivo izvajala oziroma se sploh niso, kar je med slovenskimi Nemci povzročalo veliko nezadovoljstvo, hkrati pa še okrepilo izseljevanje, ki je vrhunec doseglo konec leta 1919, ko naj bi slovensko ozemlje zapustilo približno 30.000 Nemcev (Kosi in Cvirn 2012: 71).

V Sloveniji so se v prvih letih po razpadu monarhije začeli uvajati ukrepi, ki so posegali v pravice nemške manjšine, zaradi česar so se Nemci iz Slovenije izseljevali tudi po koncu opcijskega roka. Janez Cvirn (2002) je za omenjeno politiko uporabil izraz »reasimilacija « 
oziroma ponovna asimilacija, ki je skladen s tedanjo percepcijo slovenskih oblasti, da je treba Nemce, ki naj bi bili »ponemčeni « Slovenci, popolnoma posloveniti oziroma, kot dodaja Ferenc (2005: 67), da je treba posledice raznarodovanja Slovencev iz časa Avstro-Ogrske odstraniti. Nemcem nenaklonjeno delovanje oblasti se je kazalo v ukinjanju nemških privatnih šol in reduciranju nemškega pouka na manjšinske oddelke pri državnih šolah, $\mathrm{v}$ ukinitvi večine nemških društev, $\mathrm{v}$ omejevanju rabe nemščine $\mathrm{v}$ vsakdanjem življenju, $\mathrm{v}$ omejevanju posedovanja zemljiške posesti v obmejnem pasu, nepravilnosti pa so se dogajale tudi pri štetju prebivalstva (Cvirn 2002: 112-13; Kosi in Cvirn 2012: 71).

Vprašanje ureditve položaja nemške manjšine na Slovenskem je bilo povezano tudi z vprašanjem reciprocitete glede slovenske manjšine na avstrijskem Koroškem, ki se je po vojni prav tako znašla v nezavidljivem položaju. Zamisel o kulturni avtonomiji koroških Slovencev je prišla ravno s strani predstavnikov nemške manjšine v Sloveniji (Zorn 1974: 347), ki so po ženevskem manjšinskem kongresu novembra 1925 urade na Koroškem prosili, naj uredijo slovensko manjšinsko vprašanje v skladu s sklepi konference (Zorn 1974: 350-52). Politično in gospodarsko društvo Nemcev v Sloveniji je leta 1925 poslalo koroški vladi posebno spomenico, v kateri jo je nagovarjalo, naj koroškim Slovencem prizna kulturno avtonomijo in $s$ tem pripomore k izboljšanju položaja Nemcev v Sloveniji. Januarja 1926 je isto društvo poslalo spomenico, v kateri je izrazilo upanje po ureditvi manjšinskega vprašanja tako Slovencev kot Nemcev, tudi prosvetnemu ministru v Beograd (Zorn 1974: 355; Cvirn 2002: 132-33). Ko je postalo jasno, da ureditev položaja koroških Slovencev in posledično tudi jugoslovanskih Nemcev po načelu avtonomije ne bo uresničena, je vodstvo slovenskih Nemcev idejo o recipročni ureditvi manjšinskega vprašanja opustilo. ${ }^{\mathbf{1 0}}$ Leta 1936 so jo ponovno obudili kočevski Nemci z župnikom Josefom Eppichom na čelu. ${ }^{\mathbf{1 1}}$ Leto kasneje so predstavniki koroških Slovencev in Kočevarjev podpisali skupne smernice za manjšinsko politiko: a) kakršnikoli napadi na manjšino na kulturnem, gospodarskem in političnem področju naj se ukinejo; b) uradnikom in učiteljem naj se posredujejo brezpogojne smernice glede obnašanja do manjšine; $c$ ) $v$ smislu medsebojnega razumevanja naj se cenzurirajo vsi članki v deželnih časopisih; d) kriterij narodne pripadnosti naj bo družinski jezik 1930) (Cvirn 2002: 133-34; tudi Ferenc 2005: 68-70).

11 Ta je za rešitev manjšinske problematike posredoval na Dunaju in v Celovcu (Biber 1966: 104). 
oziroma volja staršev (Biber 1966: 104). Predstavniki obeh manjšin so nato vsak svojo spomenico izročili odgovornim v Sloveniji in na Koroškem, vendar pa po vsej verjetnosti do konkretnih pogovorov sploh ni prišlo zaradi zaostritve odnosov med Jugoslavijo in Avstrijo (Biber 1966: 119-20), pa tudi zaradi »vedno bolj odkrite nacistične in iredentistične orientacije nemštva na Slovenskem « (Cvirn 2002: 141).

\section{MED PRAGMATIČNOSTJO, DEDIŠČINJENJEM IN SPOMINOM V OBDOBJU MED SVETOVNIMA VOJNAMA}

Ko so se prizadevanja Kočevarjev za ustanovitev samostojne države izjalovila, jim ni preostalo drugega, kot da se prilagodijo spremenjenim razmeram in se $\mathrm{v}$ novi jugoslovanski državi skušajo etablirati kot manjšinska skupnost. Kulturno udejstvovanje, $s$ katerim so začeli demonstrirati svojo etnično posebnost, je postalo orodje za emancipacijo, hkrati pa tudi za spodbujanje nemške identitete Kočevske, na kateri je bilo moč utemeljevati politične zahteve. ${ }^{12}$ Primer dediščinskega diskurza, ki je skozi reprezentacijo zgodovine služil utemeljevanju političnih imperativov, je praznovanje 600-letnice ustanovitve Kočevske leta 1930. Kot navaja Petschauer (1984: 110), so večdnevno prireditev organizirali, da bi opozorili na etnično zatiranje in slabo ekonomsko stanje na Kočevskem ter okrepili narodno zavednost Kočevarjev. K praznovanju so povabili kralja Aleksandra I. in druge visoke politične voditelje, saj: »Kočevarji niso nikoli zbujali vtisa, da državi niso lojalni - tako jim je narekoval razum -, a tudi ne dvoma o njihovih notranjih vezeh z njihovimi ljudmi « (Petschauer 1984: 110).

Pragmatično držo sta prevzela tudi časopisa Gottscheer Bote in njegov naslednjik Gottscheer Zeitung. ${ }^{\mathbf{1 3}}$ Poudarjati sta začela stoletno mirno sobivanje Nemcev in Slovencev na Kočevskem (glej npr. Nepodpisano 1918f: 161; 1919a: 17-8), in izražala lojalnost Kočevarjev kraljevi družini Karađorđević (glej npr. Nepodpisano 1920: 55) ${ }^{\mathbf{1 4}}$ in

Med vojnama so bila na Kočevskem nastala ali se ponovno aktivirala številna društva, na primer pevsko društvo, društvo za opazovanje ptic, športno društvo itd. (več v Hriber 1930: 218-19), ki so tudi služila temu namenu. Več o vlogi pevskega društva pri spodbujanju nemške identitete Kočevarjev v Moric 2020. nadomestil Gottscheer Zeitung. Ta je ob preselitvi v letih 1941/42 prenehal izhajati, junija 1955 pa ga je ponovno začelo izdajati kočevarsko društvo iz Celovca Gottscheer Landsmannschaft Klagenfurt. Oba časopisa sta izhajala v nemščini.

14 V mestu Kočevje je bilo v spomin kralju Aleksandru I. celo postavljeno obeležje (Nepodpisano 1934: 2-3). 
Kraljevini SHS (npr. Nepodpisano 1928d: 1). Sprva sta si vzporedno prizadevala za samoodločbo in samostojno kočevsko državo, ko pa je postalo jasno, da ta ideja ne bo uresničena, je Gottscheer Zeitung prizadevanja usmeril v doseganje manjšinskih pravic.

Spomina na nekdanjo monarhijo in lojalnost Habsburžanom se, kljub nekaterim ukrepom, ki jih je sprejela nova oblast, na primer prepovedi izobešanja slik habsburških vladarjev na javnih krajih (Nepodpisano 1921: 29), ni dalo izkoreniniti čez noč. K priljubljenosti habsburške vladarske hiše širom monarhije, tudi na Kočevskem, je v veliki meri pripomoglo osnovno šolstvo s svojo državljansko vzgojo. »Šolska zgodovina ni bila zgodovina avstrijske države, ampak je bila v resnici zgodovina Habsburžanov. V šolah so bile pogoste proslave ob obletnicah rojstev, porok in smrti vladarjev in drugih članov vladarske hiše « (Maček 2020: 281). Po besedah Marthe iz New Yorka, ${ }^{15}$ ki je otroštvo preživela na Kočevskem, so bili Kočevarji » prepričani Avstrijci, njihovi sinovi so služiliv avstro-ogrskih vojskah. Mama je ljubeče govorila o svojih šolskih dnevih [...], ko so v šoli praznovali cesarjev rojstni dan s prepevanjem stare himne 'Gott erhalte, Gott beschütze unsern Kaiser, unser Land ...' « Cesar Franc Jožef I. je bil »že za časa življenja legendarna osebnost - tudi, in posebno za Kočevarje. Kočevska je bila monarhu blizu, predvsem zaradi princa Karla von Auersperga. Cesar je vedno znova odgovarjal na prošnje Kočevarjev za pomoč z dodeljevanjem sredstev iz svojih zasebnih fondov « (Petschauer 1984: 103). Kljub temu, da so namesto proslav ob rojstnih dnevnih, porokah in smrtih Habsburžanov po novem praznovali jubileje Karađorđevićev in jim hkrati izražali zvestobo, se je vzporedno obdržala tudi lojalnost do nekdanje vladarske hiše.

Ohranjanje spomina na Avstro-ogrsko monarhijo in izražanje nemške identitete Kočevarjev sta se med drugim kazala v spomenikih in sporočilih spominskih slovesnosti, ki so se odvijale na novo nastalih »krajih spomina «. Spomeniki prve svetovne vojne na Kočevskem so bili več kot zgolj ohranjevalci spomina na padle vojake, saj so, kot bo prikazano v sledečem razdelku, hkrati slavili državo, za katero so ti žrtvovali svoja življenja. A vendar kljub dejstvu, da je bila v jugoslovanski državi, v kateri so se znašli tako zmagovalci kot poraženci vojne in istočasno postavljali spomenike svojim žrtvam, produkcija spomenikov padlim v prvi svetovni vojni kočljiva (Nepodpisano 2018a: 3), podatka o tem, da bi na Kočevskem ob odprtju spomenikov prihajalo do (nacionalnih) nasprotij, nisem zasledila. ${ }^{\mathbf{1 6}}$

16 Časopis Slovenec je na primer odkritju spomenika v Stari Cerkvi, namenil zgolj kratko nevtralno notico (Nepodpisano 1926d: 5). 
Spominjanje na prvo svetovno vojno je zaznamovalo dejstvo, da so imeli prebivalci novonastalega Kraljestva Srbov, Hrvatov in Slovencev »drugačne, celo nasprotujoče si vojne izkušnje, ki so oteževale vzpostavljanje skupnega spomina « (Štepec 2018: 10), kar je bilo prisotno tudi na Kočevskem, kjer v postavljanju spomenikov, kapel in obeležij v spomin na padle vojake ali v zahvalo za njihovo srečno vrnitev domov niso zaostajali za ostalimi slovenskimi ali srednjeevropskimi pokrajinami. Kočevarji so bili celo med prvimi prebivalci območja (kasnejše) Dravske banovine, ${ }^{\mathbf{1 7}} \mathrm{ki}$ so obeležili spomin na žrtve iz svojih vrst. Spomenike padlim vojakom ali žrtvam vojne so, tako kot drugod (Čopič 2000: 87-8), postavljali na pokopališčih, pri cerkvah ali na drugih javnih krajih, pri njihovem nastanku pa so veliko vlogo odigrali tudi politični dejavniki.

Prvo spominsko tablo padlim v prvi svetovni vojni so postavili v cerkvi sv. Mihaela v Borovcu 1. septembra 1922 (Nepodpisano 1926c; Nepodpisano 1922: 139-40). Meter visoko in 80 centimetrov široko ploščo iz sivega carrarskega marmorja, ki jo je izdelalo lokalno kamnoseško podjetje Wenchiarutti und Stender iz Štalcerjev, so pritrdili na desno stran cerkvene ladje pod prižnico. Na vrhu table je bil vklesan križ, obdan z dvema lovorovima vencema, $\mathrm{v}$ osrednjem delu pa so bila skupaj s kraji njihovega rojstva in vojaškimi čini z zlatimi črkami zapisana imena padlih vojakov. Časopis Gottscheer Zeitung (Nepodpisano 1922: 139-40) je objavil imena enajstih darovalcev - ameriških Kočevarjev, ki so omogočili postavitev te »častne table«, in poročal, da so se zaradi ganljivega govora župnika Josefa Perza večini navzočih orosile oči. ${ }^{18}$ Jutranjo slavnostno mašo za umrle z libero je zaokrožil nastop mešanega pevskega zbora, ki je ob orgelski spremljavi zapel pesem Po Božji volji (Es ist bestimmt in Gottes Rat) (Nepodpisano 1922: 139-40).

Čez štiri leta so Borovčanom v velikem slogu sledili prebivalci Stare Cerkve. Če so bili spomeniki na slovenskem podeželju večinoma deležni le skromne slovesne otvoritve, časopisi pa so jim namenili zgolj kratke notice (Čopič 2000: 97), je bilo s spomenikom v Stari Cerkvi drugače. Sklepati gre, da je za to poskrbel verjetni idejni vodja 


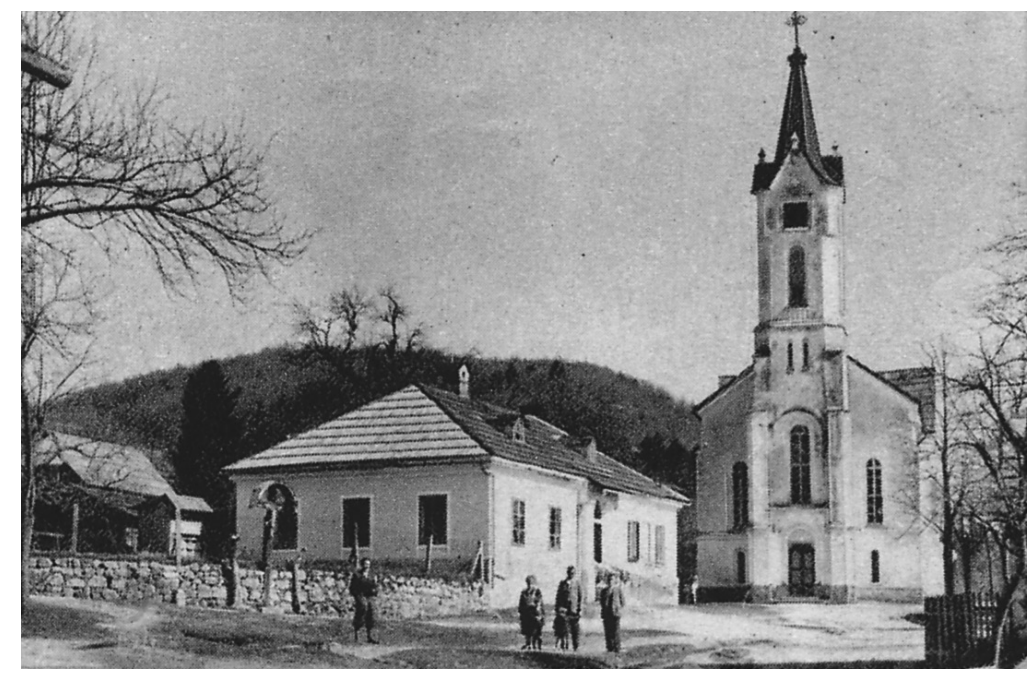

Slika 2: Razglednica Borovec, avtor fotografije Josef Dornig, okoli leta 1935. Hrani: Pokrajinski muzej Kočevje

postavitve spomenika, župnik in politik, Josef Eppich. ${ }^{\mathbf{1 9}}$ Časopis Gottscheer Zeitung, ki ga je omenjeni urednikoval, je opisu spomenika, otvoritveni slovesnosti in Eppichovemu govoru posvetil celo stran (Nepodpisano 1926c: 1-2). Plošča iz kraškega in belgijskega črnega marmorja, visoka 2,46 metra in široka 1,50 metra, iz delavnice ljubljanskega kamnoseka Alojza Vodnika, ${ }^{20}$ ki so jo vdelali na levi bok zvonika cerkve Marijinega vnebovzetja, si je, kot je poročal časnik, »prislužila hvalo domačinov in tujcev« (Nepodpisano 1926c: 1). Zbiranje 14.000 dinarjev za njeno izdelavo je prevzel kaplan Hermann Michel in je trajalo dalj časa, ${ }^{\mathbf{2 1}}$ saj je del zneska manjkal še konec decembra, ko so Kočevarji iz Amerike zanjo darovali 4200 dinarjev (Nepodpisano 1926e: 4) oziroma skoraj tretjino celotne kupnine. Osrednji del plošče pripada napisu v nemščini: »Žrtve svetovne vojne 1914-1918 iz župnije Stara Cerkev« (Mitterdorf) in imenom šestdesetih vojakov,

Župnik Josef Eppich je v Stari Cerkvi služboval med leti 1902 in 1941. Leta 1904 je bil med ustanovitelji časopisa Gottscheer Bote, leta 1919 pa je ustanovil časopis Gottscheer Zeitung, katerega urednik in pisec je ostal do 1939. Bil je vodja Kočevske kmečke zveze in član glavnega odbora leta 1924 ustanovljenega Političnega in gospodarskega združenja Nemcev v Sloveniji. Leta 1927 je bil v Kočevskem okraju izvoljen v za poslanca skupščine v Ljubljani. V 1930-h letih je bil aktiven pri recipročnem urejanju manjšinskega statusa.

Oblikovno podobni spominski tabli iz Vodnikove delavnice sta bili v letih 1925 in 1926 vzidani na pročelje cerkve sv. Križa v Jurjevici pri Ribnici (Češarek 2018: 86), po čemer lahko sklepamo, da je šlo za tipski izdelek omenjenega kamnoseka. 


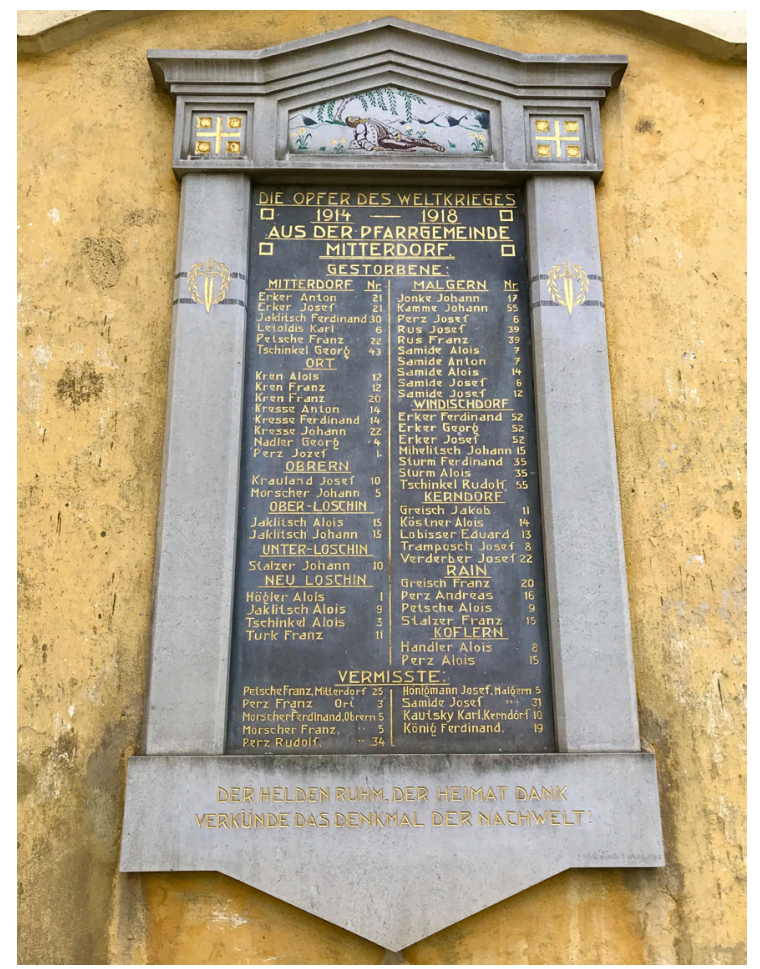

Slika 3: Spominska plošča z imeni padlih v Stari Cerkvi (foto: Anja Moric, 2018).

nanizanim po abecednem vrstnem redu, po vaseh, kjer so živeli, skupaj $s$ hišnimi številkami. Vrh spomenika krasi podoba padlega avstro-ogrskega vojaka $\mathrm{v}$ polni oborožitvi, ležečega $\mathrm{v}$ idilični pokrajini.

Nov kraj spomina ni bil izbran naključno, saj so spominsko tablo postavili na dobro vidnem mestu v samem središču Stare Cerkve - eni izmed najstarejših vasi oziroma prvem »jedru gostejšega naseljevanja « (Rus 1939: 133) in prvem krščanskem središču (Erker 1930b: 50) na Kočevskem. Tam ni bila na ogled le vaščanom, pač pa tudi številnim romarjem iz Kočevja in okoliških vasi, ki so vsako leto ob velikem šmarnu, 15. avgusta (Kundegraber 1962: 250), prihajali k cerkvi Marijinega vnebovzetja, zgrajeni (leta 1853) na mestu, kjer je že pred letom 1339 stala najstarejša cerkev na Kočevskem (Simonič 1939: 55). $\mathrm{Na}$ starem pokopališču ob cerkvi so Kočevarji od časa srednjeveške priselitve dalje pokopavali svoje rajne (Nepodpisano 1926c: 2). ${ }^{\mathbf{2 2}}$ Postavitev spomenika in spremljajoča slovesnost na tem, za Kočevarje 
pomembnem kraju, sta pomenili simbolno slovo od mož in mladeničev iz župnije Stara Cerkev, katerih trupla so večinoma ostala na oddaljenih bojiščih. Od šestdesetih padlih, ki jim je spomenik posvečen, jih je bilo le sedem pokopanih v domači zemlji, in sicer štirje na pokopališču v Stari Cerkvi, trije pa v Mali Gori. V času postavitve je bilo še vedno pogrešanih devet oseb, katerih imena so pod oznako » pogrešani « dodali seznamu padlih. Da bi dosegli pridih svetega prostora, so spomenik ogradili s kovano ograjo iz delavnice lokalnega ključavničarskega mojstra Eppicha. Na tem zgodovinsko pomembnem »posvečenem « (pa tudi dobro vidnem in obiskanem) kraju bodo, kot je dejal župnik Josef Eppich: » za vse večne čase z zlatimi črkami zapisana imena naših vojakov pričala o časti kočevarskih ljudi « (Nepodpisano 1926c: 2).

Blagoslov plošče ob romarskem prazniku malem šmarnu, ${ }^{\mathbf{2 3}}$ 8. septembra 1926, je spremljalo veliko slavje, ki se ga je udeležilo mlado in staro. Po uvodnem nastopu pevskega zbora starocerkovških intelektualcev je zbrane nagovoril župnik Eppich, spomenik pa je posvetil kočevski dekan Ferdinand Erker. Zbor je zapel še dve pesmi. Vence so položili Odbor za spomenik, Invalidsko združenje, predstavništvi Stare Cerkve in Male Gore ter gasilci. Sledila je slavnostna maša, popoldne pa slovesne večernice (Nepodpisano 1926c: 2). Na veselici, ki je trajala vse do nočnih ur (Nepodpisano 1926b: 3) sta igrali kar dve godbi. Prireditve so se udeležili celo gasilci iz oddaljene Gotenice (Nepodpisano 1926c: 2).

Spomenik v Stari Cerkvi ni služil le počastitvi spomina na padle iz župnije Stara Cerkev, temveč tudi legitimiranju kočevarske narodne, to je nemške identitete, kar izpričuje epitaf pod ploščo v nemščini: »Slavo junakov, hvaležnost domovini, spomenik, oznanjaj prihodnjim rodovom! « Z njim so kočevski Nemci simbolno izrazili pripadnost nekdanji državi Avstro-Ogrski. Da je bil spomenik obenem nosilec spomina na vojake in na monarhijo, za katero so ti dali življenja, lahko sklepamo tudi iz govora župnika Eppicha:

Kdo nima spoštovanja do vseh, ki so bili iztrgani z naše sredine in so s svojim telesom domovino (poudarila A. M.) pred opustošenjem varovali in vsem težnjam navkljub v priseženi dolžnosti vztrajali, četudi so mnogi svoje zdravje izgubili in postali invalidi. Največjo hvaležnost dolgujemo brez dvoma tistim, ki so med vojno izgubili življenja. Tem junakom povsod po svetu postavljajo spomenike in želijo ohraniti spomin nanje tudi za prihodnje rodove. Stara Cerkev ni hotela izostati, zato naj bo danes odkrit in posvečen spomenik na 
žrtve svetovne vojne iz naših župnij, da bi lahko vsem, ki prihajajo za nami, pričal o slavi naših junakov in hvaležnosti naše župnije.

(Nepodpisano 1926c: 1-2)

Spomeniki in spominska obeležja imajo, skupaj s komemoracijami, pomembno vlogo pri interpretaciji kolektivnega spomina ter kreiranju in ohranjanju mitov, saj zaradi okoliščin, kako so tisti, ki so jim postavljena, umrli ali za katere ideale so se bojevali, ostajajo del življenj poznejših generacij (Luthar 2011: 175). Spominska plošča v Stari Cerkvi je služila kot vez s preteklostjo in kot sredstvo za njeno interpretacijo. Slovesnosti in slavnostni nagovori, ki so potekali ob plošči, so preteklost osmišljali in skrbeli za to, da padli vojaki pa tudi nekdanja država, za katero so ti dali svoja življenja, niso utonili v pozabo.

Skoraj leto dni po otvoritvi spomenika, 9. oktobra 1927, so v Stari Cerkvi praznovali dan invalidov, ki so se ga udeležili člani Združenja invalidov, svojci padlih vojakov, gasilci, duhovščina in farani. Po cerkvenemu slavju so se udeleženci zbrali pred lepo okrašenim spomenikom, kjer je potekal simbolen blagoslov vseh vojaških grobov. Župnik Eppich jih je pozval, naj spoštujejo in častijo ne le padle, pač pa tudi še živeče junake in invalide, ki so za dobrobit domovine

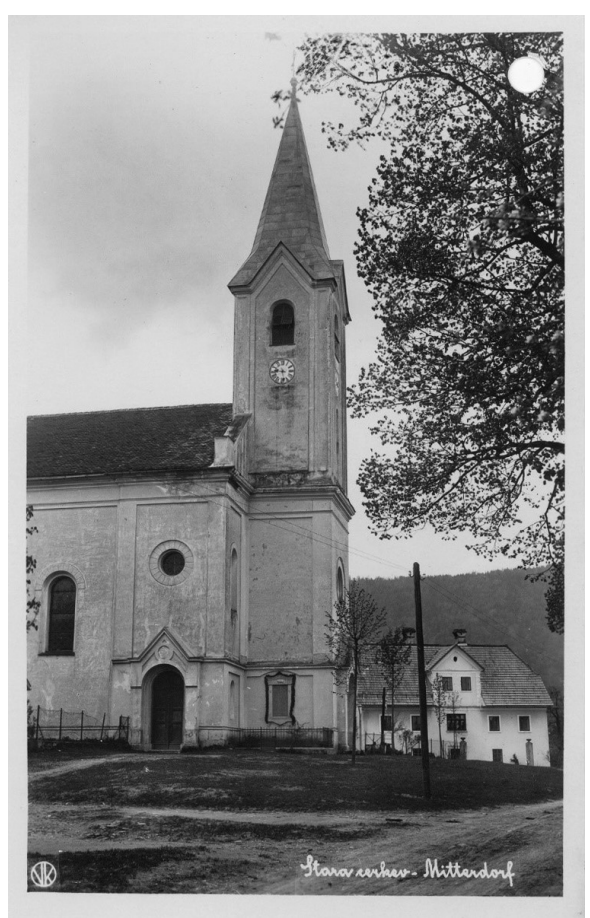

Slika 4: Cerkev Marijinega vnebovzetja v Stari Cerkvi, spominska tabla je okrašena z zelenjem. Avtor fotografije: Vekoslav Kramarič (med leti 1928 in 1947). Hrani: Slovenski etnografski muzej. 
tvegali svoje zdravje. Popoldan se je druženje nadaljevalo v polni gostilni Mathiasa Sigmunda, kjer so v ta namen spekli celega prašiča. Veselo razpoloženje, kjer ni manjkalo ne glasbe niti pijače, je trajalo do polnoči, ko se je zaključilo z nagovorom predsednika društva in navdušenimi vzkliki domačinov (Nepodpisano 1927a: 2).

Konec oktobra 1927, leto pred deseto obletnico konca prve svetovne vojne, je pred praznikom Vseh svetih Gottscheer Zeitung objavil pismo anonimnega »rojaka iz Celovca «, v katerem je Kočevarje nagovoril, naj težkim gospodarskim razmeram navkljub v večji meri obeležujejo spomin na svoje padle. Predlagal je, naj se, kot je v navadi v Avstriji in Nemčiji, v farah, kjer nimajo zadostnih sredstev za postavitev spomenika, imena padlih zapišejo na papir, uokvirijo in izobesijo $\mathrm{v}$ cerkvah poleg kropilnika.

\begin{abstract}
Priporočljivo bi bilo, da bi ta seznam vsako leto na dan vseh svetnikov predstavili s prižnice in ob tem zmolili Očenaš. Če duhovnika ni, lahko obred opravi molitveni vodja ali domačin v prijetni vaški cerkvi ali na pokopališču. Na vsakem pokopališkem križu, tudi pri podružnicah, tega dne ne sme manjkati velik venec iz jelovih vej, spleten z ljubeznijo in naklonjenostjo,
\end{abstract}

je še pozval pisec in priporočil naj po vzoru nemških dežel, slovesnosti spremlja tudi prepevanje junaških pesmi (Nepodpisano 1927b: 2).

Predlog je padel na plodna tla, saj so ga že novembra udejanjili v Gotenici. Uokvirili so spominski list Rdečega križa, velikosti 40 krat 51 centimetrov, na katerem je bilo pet upodobitev z vojnih prizorišč. Rdeči križ so nadomestili s črnim in na sredo lista zapisali imena desetih padlih bojevnikov iz goteniške fare ter prošnjo vernikom, naj jih počastijo z molitvijo. »Spominski list je postavljen na primerno mesto v cerkvi in naredi dober vtis «, je poročal Gottscheer Zeitung (Nepodpisano 1927c: 4).

Konec leta 1927 je prinesel pobudo za postavitev spomenika tudi $\mathrm{v}$ upravnem in kulturnem središču Kočevske. Na predlog lokalnega invalidskega združenja Gottscheer Invalidenverband se je postavilo vprašanje postavitve spomenika junakom, padlim v mestni župniji Kočevje, pri kateri bi po mnenju pobudnikov poleg mesta Kočevja morale sodelovati tudi ostale vasi iz omenjene fare. Društvo je v nedeljo, 18. decembra 1927, ob 14. uri sklicalo sestanek v gostilni Hönigmann-Gruber, na katerem naj bi izvolili pripravljalni odbor in razpravljali o ostalih podrobnostih. Vaške skupnosti so pozvali, naj na to srečanje pošljejo svoje predstavnike (Nepodpisano 1927d: 2). Podatka o tem, kaj se je zgodilo z idejo o postavitvi spomenika, tekom raziskave nisem našla. Leta 1929 so nameravali spomenik 
postaviti tudi v vasi Novi Lazi, saj je tamkajšnji odbor za spomenik 1. maja 1928 v Gottscheer Zeitungu poročal o 2640,95 dinarjih, ki so jih v ta namen poslali Kočevarji iz Amerike oziroma iz Clevelanda (Nepodpisano 1928a: 6). Kočevarji iz Brooklyna (New York) pa so oktobra 1928 prispevali 58,50 dolarjev za postavitev spomenika v Kočah (Nepodpisano 1928b: 3).

Poleg skupnih spomenikov, ki so jih postavljale lokalne skupnosti, je prihajalo tudi do bolj »intimnih « družinskih postavitev, ko so svojci posebna obeležja $\mathrm{v}$ spomin posameznim padlim sorodnikom postavljali na pokopališčih. Spominski kamen je deset let po koncu vojne na pokopališču v Podlesju (Verdreng) svojim trem padlim bratom, Johannu, Josefu in Matthiasu Schemitschu, postavil Leopold Schemitsch iz Brooklyna z brati (Nepodpisano 1928c: 8).

Če so spominske table in nagrobniki pričali o vojnih žrtvah, pa so po drugi strani nastajale tudi kapele in križi v zahvalo za srečno vrnitev domov. Kapelica Matere Božje, ki so jo ob množični udeležbi slovesno posvetili 2. oktobra 1921, je stala na poti iz Kočevja proti Stari Cerkvi in Mali Gori (Eppich 1925: 74). Izgradnjo, ki je stala 18.000 kron, sta v zahvalo za srečno vrnitev svojih mož iz vojne plačali Maria Tscherne in Josefa Eppich iz Mahovnika. Župnik Josef Eppich (1925: $74)$ je poročal, da so se mestni sprehajalci, pa tudi obiskovalci Kočevja in rudarji, ki so se vračali iz premogovnika, radi ustavili pred čudovito podobo, ki je celo dobila električno razsvetljavo. Napovedal je, da bo poleg kapele zasajena lipa z leti prostor še polepšala, a se je motil. Danes ne najdemo več niti kapele niti lipe.

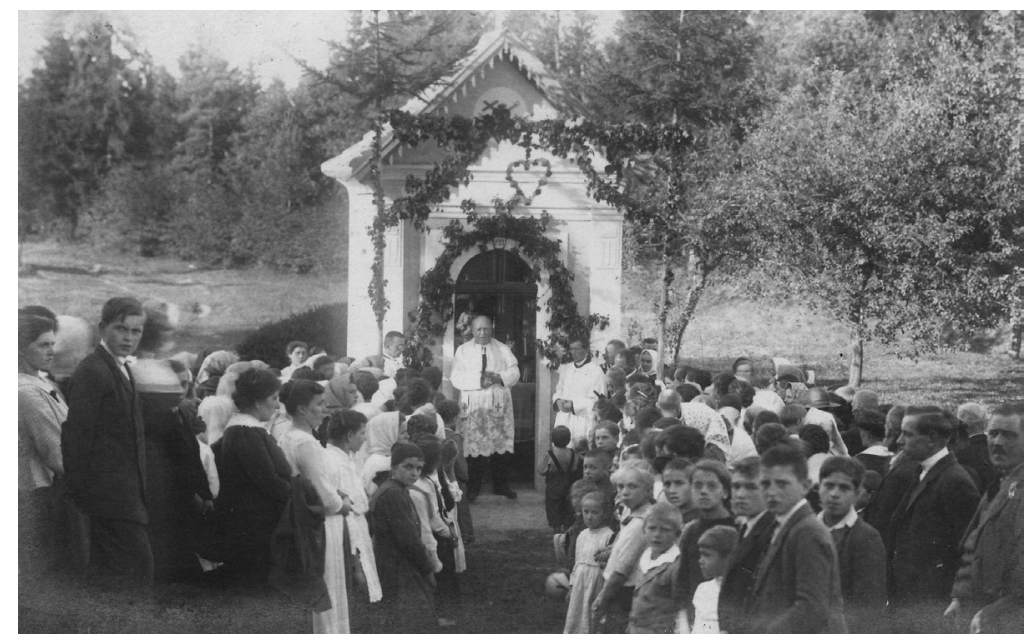

Slika 5: Posvetitev kapele Matere Božje je vodil dekan Ferdinand Erker. Avtor fotografije: Josef Dornig. Razglednico hrani Muzej krščanstva na Slovenskem. 
Na srečno vrnitev iz vojne na širšem Kočevskem spominjata še (vsaj) dve znamenji. Kamnit križ je v Mirtovičih ob cesti Mirtoviči-Petrina postavil Anton Štimec iz Mirtovičev. Kočevarska družina iz vasi Seč (Gehack), na belokranjskem delu nekdanjega kočevarskega poselitvenega območja, pa se je za vrnitev treh sinov zahvalila s postavitvijo kapelice Srca Jezusovega (Jože Vene; ${ }^{\mathbf{2 4}}$ glej tudi Zupan in Ferenc 2013).

Spominska tabla v Stari Cerkvi je danes edino ohranjeno ${ }^{25}$ spominsko obeležje padlim $\mathrm{v}$ prvi svetovni vojni na širšem Kočevskem. Marmorna tabla iz cerkve Sv. Mihaela v Borovcu je izginila skupaj s cerkvijo, ki jo je leta 1943 požgala italijanska vojska, ruševine pa so bile leta 1952 odstranjene (Zupan idr. 1993: 47). Cerkev sv. Lenarta v Gotenici, kjer je bil shranjen spominski list z imeni goteniških žrtev, je bila porušena okrog leta 1950 (Zupan idr. 1993: 78). Sklepamo lahko, da je obstajalo še več kapel ali križev v spomin na prvo svetovno vojno, ki pa so bili med in po drugi svetovni vojni skupaj z večino sakralnih objektov na Kočevskem uničeni in o katerih pričajo le še skopi časopisni (morda tudi še neobdelani arhivski) viri. Izgubljena je tudi večina nemških pokopališč in nagrobnikov, ki bi pričali o pokopanih vojakih.

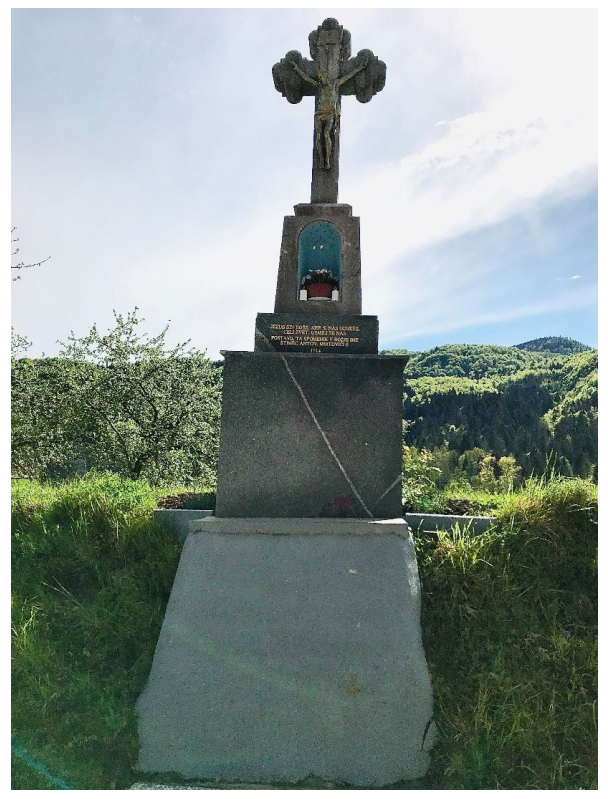

Slika 6: Mihejlov križ iz leta 1914v Mirtovičih ob cesti Mirtoviči - Petrina (foto: Anja Moric, 2019) sela, kapelico obnovil.

25 Spomenik je leta 2009 dalo obnoviti Kočevarsko društvo iz Celovca (Nepodpisano 2009: 18). 


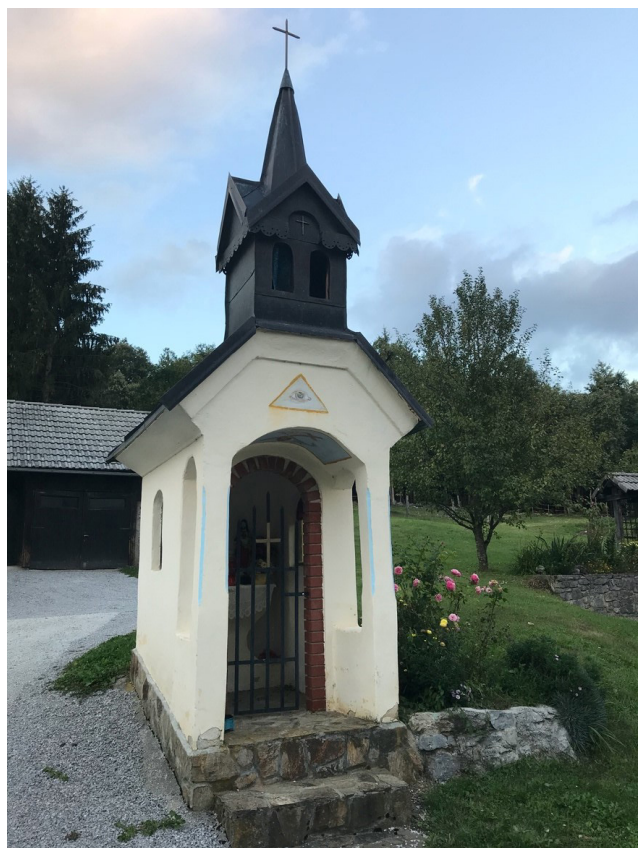

Slika 7: Kapelica Srca Jezusovega v Seču, postavljena v zahvalo za srečno vrnitev treh bratov iz vojne (foto: Anja Moric, 2020).

\section{KONEC KONCA? - MED SPOMINOM IN POZABO}

Ob koncu prve svetovne vojne je zmagalo »načelo nacionalnosti «, po katerem so v Evropi (in drugod) sistematično poskušali zarisati nov politični zemljevid (Hobsbawm 2007: 157-59).

Vendar pa z Wilsonovim načelom ni bilo mogoče doseči, da bi državne meje ustrezale nacionalnim in jezikovnim mejam. [...] Ta princip kratko malo ni deloval. Ker so bila ljudstva pač tako poseljena, je bila večina novih držav, ki so nastale na ruševinah nekdanjih imperijev, nujno prav tako multinacionalna kakor stare »ječe narodov«, ki so jih nadomestile. (Hobsbawm 2007: 159)

Tudi kočevarski primer opozarja na etnično oziroma jezikovno raznoterost nekdanjega imperija in dejstvo, da politične spremembe, ki so Slovencem prinesle želeno emancipacijo, niso razveselile vseh prebivalcev nove države. V obdobju med vojnama se je etnično razlikovanje še okrepilo in sprožalo vedno nove konflikte na jezikovno mešanih območjih. Na Kočevskem je šla situacija celo tako daleč, da je med drugo 
svetovno vojno v letih 1941/42 večina kočevskih Nemcev - 11.509 (Ferenc 2002: 155) po pogodbi med Hitlerjem in Mussolinijem optirala za preselitev v nemški rajh. Danes so njihovi potomci razseljeni po vsem svetu, večina jih živi v ZDA, Kanadi, Avstriji in Nemčiji, le peščica jih je ostala na Kočevskem.

Prva svetovna vojna je kočevarski skupnosti ostala v spominu kot točka preloma oziroma kot ločnica med idealizirano preteklostjo in neprijetno sedanjostjo. Ob stoletnici konca vojne leta 2018 so Kočevarji v Avstriji 53. Kočevarski kulturni teden, prireditev, ki jo od leta 1966 vsako leto organizirajo pri gradu Hrastovec v bližini Celovca, pomenljivo podnaslovili kot »Začetek konca kočevske dežele «(Nepodpisano 2018b). ${ }^{26}$ Prehod iz avstro-ogrske v jugoslovansko državo je v kolektivnem spominu Kočevarjev zapisan kot žalostno dejstvo, ki je prineslo izgubo pravic - zlasti pravice do rabe nemškega jezika $\mathrm{v}$ šolah in povzročilo začetek konca obstoja kočevarske skupnosti na Kočevskem. Mit o trpljenju pod jugoslovansko oblastjo (Moric 2016: 217) se kot pospomin (postmemory) (Hirsch 2011: 347) še desetletja po drugi svetovni vojni prenaša z generacije na generacijo Kočevarjev, ki, čeprav travmatičnega medvojnega dogajanja niso sami doživeli, to občutijo kot lastno izkušnjo (Moric 2016: 217; gl. tudi Thomason 2010: 47). Zanimivo je, da korenine tega mita segajo v čas pred dejanskim nastankom novih meja in spremembo medetničnih razmerij na Kočevskem. Prve zahteve po samostojnosti Kočevske namreč kažejo na to, da se je mit o »slabi «ugoslaviji, ki je temeljil na protisrbski propagandi, med Kočevarji razširil še pred dejanskim nastankom jugoslovanske države. Če so slovenski nacionalistični aktivisti promovirali odpor do Habsburškega cesarstva, ki so ga, da bi sami etablirali svoje nacionalne ideje, prikazovali kot zatiralca malih narodov (glej Judson 2018), so na drugi strani enako počeli kočevarski (verski in politični) voditelji, ki so ob začetku prve svetovne vojne nasprotovali »zlobni« Srbiji, sovražnici Avstro-ogrskega cesarstva, ob koncu vojne pa skupni državi Jugoslovanov. Spomin na kršenje manjšinskih pravic med vojnama je po drugi svetovni vojni prevzel vlogo potrdila njihove vloge žrtve $\mathrm{v}$ svetovni politiki, zaradi katere so zapustili svoje domove in se preselili v nemški rajh. V tej naraciji se je siceršnje sobivanje, o katerem poročajo tako Slovenci kot Nemci, pozabilo. ${ }^{\mathbf{2 7}} \mathrm{K}$ pozabi nekdanje večjezičspremembe « (Nepodpisano 2019). Podobne odzive na nove razmere, s katerimi so se po vojni srečali Kočevarji, najdemo tudi v drugih kočevarskih publikacijah in objavljenih spominih (glej npr. Kren 2013: 42; Krauland 1994: 17). 
nosti in etničnega sožitja na Kočevskem je pripomogla tudi pretrgana kontinuiteta poselitve oziroma večinska zamenjava prebivalstva. ${ }^{\mathbf{2 8}}$

Po drugi svetovni vojni je kulturna dediščina na Kočevskem doživela podobno tragično usodo, kot njeni nekdanji prebivalci. Če so drugje po Sloveniji spomeniki prvi svetovni vojni izginjali v pozabo zaradi nadomestitve s spomeniki drugi svetovni vojni, je bila na Kočevskem zgodba drugačna. Odnesla jih je vojna, saj je stavbna dediščina med italijansko ofenzivo leta 1941 utrpela ogromno škodo. Ubežali niso niti povojni vihri, ki je želela izbrisati vse, kar je spominjalo na nekdanje nemške prebivalce, in je zaradi sočasnega protiverskega sentimenta vse do 1960 -ih let rušila cerkve in kapele. ${ }^{29}$ Skupaj s sakralno dediščino so izginili tudi spomeniki padlim vojakom. Ostal je le najpomembnejši - spomenik v Stari Cerkvi, ki zaradi sporočila v nemščini, ni le ohranjevalec spomina na padle vojake in državo, za katero so se borili, temveč tudi priča o pogledu na novonastalo politično situacijo, v kateri so se po prvi svetovni vojni znašli Kočevarji.

\section{CITIRANE REFERENCE}

Arko, Hans s. d. »Gedachtnisschrift.« Gedächtnisschrift, Dr. Hans Arko, Advokat in Gottschee, keine Datierung - wahrscheinlich Ende November 1941. Internetni vir. http://www.gottschee.de/Dateien/Dokumente/Web\%20Deutsch/ Arko/ Gedaechtnisschrift.htm. Dostop 10. april 2020.

BARTH, FREDRIK 1998 Introduction; Fredrik Barth, ur. Ethnic groups and boundaries: the social organization of culture difference, str. 9-38, Illinois: Waveland press.

Biber, DUšan 1963 Kočevski Nemci med obema vojnama. Zgodovinski časopis, št. 1, str. 23-42.

1966 Nacizem in Nemci v Jugoslaviji 1933-1941. Ljubljana: Cankarjeva založba.

Cornwall, Mark 2015 The Spirit of 1914 in Austria-Hungary; Prispevki za novejšo zgodovino, št. 2, str. 7-21.

Cvirn, JANEZ 2002 Nemci na slovenskem (1848-1941); Dušan Nećak, ur. Zbornik: »Nemci« na Slovenskem 1941-1955, str. 99-144. Ljubljana: Znanstveni inštitut Filozofske fakultete.

ČEŠARE K, DOMEN 2018 Spomeniki in obeležja padlim v prvi svetovni vojni; Lucija Kos Bartol ur. Konec je vélike vojne: nikoli več?, str. 82-91. Ribnica: JZ Rokodelski center - zavod za rokodelstvo, muzejsko in galerijsko dejavnost.

28 Po drugi svetovni vojni je na Kočevskem ostalo manj kot 600 kočevskih Nemcev. V opuščene vasi in hiše so se začeli naseljevati priseljenci iz drugih slovenskih krajev (Ferenc 2005: 269).

29 Zaradi ideološke (protiverske) in protinemške nestrpnosti je bilo porušenih kar 95 od 123 cerkva in kapel, od več kot 400 kapelic in znamenj pa jih stoji le še 38 (Ferenc 2005: 659-70). 
ČOPIČ, ŠPELCA 2000 Javni spomeniki v slovenskem kiparstvu prve polovice 20. stoletja. Ljubljana: Moderna galerija.

Eppich, Josef 1925 Die Gelöbniskapelle beim Krahwirt; Gottscheer Kalender, št. 5, str. 74.

1930a Der Weltkrieg und die Pfarre Mösel; Gottscheer Kalender, št. 10, str. 53.

1930b Kirchen- und Pfarrgründungen im Gottscheer Gebiete; Josef Erker, ur. Jubiläums-Festbuch der Gottscheer 600-Jahresfeier: aus Anlaß des 600-jährigen Bestandes des Gottscheer Landes, str. 47-67. Gottschee: Festausschuss der Gottscheer 600-Jahrfeier.

FERENC, Mitja 2005 Kočevska - pusta in prazna: nemško jezikovno območje na Kočevskem po odselitvi Nemcev. Ljubljana: Modrijan.

Ferenc, Tone 2002 Nemci na Slovenskem med drugo svetovno vojno; Dušan Nećak, ur. Zbornik: »Nemci《 na Slovenskem 1941-1955, str. 145-190, Ljubljana: Znanstveni inštitut Filozofske fakultete.

Grothe, Hugo 1931 Die deutsche Sprachinsel Gottschee in Slowenien: ein Beitrag zur Deutschtumskunde des europäischen Südostens. Münster: Aschendorffsche Verlagsbuchhandlung.

Hauffen, Adolf 1895 Die Deutsche Sprachinsel Gottschee. Geschichte und Mundart, Lebensverhältnisse, Sitten und Gebraüche, Sagen, Märchen und Lieder. Graz: K. K. Universitäts-Buchdruckerei und Verlags-Buchhandlung »Styria «.

Hirsch, Marianne 2011 Marianne Hirsch, from »The generation of Postmemory «; Jeffrey K. Olick, Vered Vinitzky-Seroussi in Daniel Levy, ur. The Collective Memory Reader, str. 346-347. New York: Oxford University Press.

НовSBAWM, ERIC J. 2007 Nacije in nacionalizem po letu 1780: program, mit in resničnost. Ljubljana: Založba /*cf.

Hriber, Franz 1930 Die Vereinswesen in Gottschee. Josef Erker, ur. Jubiläums-Festbuch der Gottscheer 600-Jahresfeier: aus Anlaß des 600-jährigen Bestandes des Gottscheer Landes, str. 215-219, Kočevje: Festausschuss der Gottscheer 600-Jahrfeier.

Judson, Pieter M. 2018 Habsburški imperij: nova zgodovina. Ljubljana: Sophia.

Komac, Miran, in Dean Zagorac 2002 Varstvo manjšin: uvodna pojasnila \& dokumenti. Ljubljana: Društvo Amnesty International Slovenije in Inštitut za narodnostna vprašanja.

Kosi, JerneJ, in Janez Cvirn 2012 Nemški begunci v Avstriji; ur. Jerneja Ferlež, ur. Nemci in Maribor: Stoletje preobratov 1846-1946, str. 62-64. Maribor: Umetniški kabinet Primož Pemzl.

Krauland, Edeltraud M. 1994 Gottschee: The Resettlement Years. Wyoming: Pioneer Printing.

KREN, LUDWIG 2013 Gottschee 1339-1941: Eine Errinerung. Maria Rain.

Kundegraber, Maria 1962 Die Wallfahrten der Gottscheer: Versuch einer Bestandsaufnahme (Mit einer Karte und sieben Abbildungen); Österreichische Zeitschrift für Volkskunde, št. XVI, str. 233-265. 
LUTHAR, Ото 2011 »Dokler nas smrt ne loči«. Moderna spominska pokrajina in nacionalizacija kolektivnega spomina po prvi svetovni vojni; Tanja Petrović, ur. Politike reprezentacije v Jugovzhodni Evropi na prelomu stoletij, str. 173-199. Ljubljana: Založba ZRC.

MAČEK, JožE 2020 Pieter M. Judson, Habsburg. Geschichte eines Imperiums 17401918. Aus dem Englischen von Michael Muller. München: Verlag C. H. Beck, 2017, 667 str. Zgodovinski časopis, št. 1-2, str. 278-283.

MAKAROviČ, MARIJA IDR. 2002 Dva bregova eno srce: Življenjske pripovedi iz doline Kolpe in Čabranke. Kočevje: Pokrajinski muzej Kočevje.

Marcus, George E. 1995 Ethnography in/of the World System: The emergence of multi-sited ethnography; Annual Rewiev of Anthropology, št. 24, str. 95-117.

Moric, ANJA 2010 Ohranjanje kočevarščine, narečja kočevskih Nemcev, v Sloveniji, Avstriji, Nemčiji, Kanadi in ZDA; Razprave in gradivo, št. 61, str. 92-119.

2016 Slovenski Nemci v diaspori. Doktorska naloga. Ljubljana: Univerza v Ljubljani, Fakulteta za družbene vede.

2020 Gottscheer folk song - from a means of national differentiation fostering to a memory keeper in the diaspora; Traditiones 49(2), DOI: https://doi. org/10.3986/Traditio2020490208.

NePODPISANO 1916 Der Kronprinz Inhaber des krainischen Infanterie - Regiments Nr. 17; Gottscheer Bote, 4. decembra, str. 184.

1918a Gottschee und der südslawische Staat. Eine Entschließung der deutschen Geistlichkeit des Gottscheer Gebietes; Gottscheer Bote, 4. februarja, str. 17-19.

1918b Gottschee und die südslawische Frage. Eine Entschließung der Stadtgemeindevertretung von Gottschee; Gottscheer Bote, 4. aprila, str. 50-51.

1918 c Die Südösterreicher beim Kaiser. Eine historische Audienz; Gottscheer Bote, 4. junija, str. 81-82.

1918d Wilson als Friedenshinderer; Gottscheer Bote, 19. julija, str. 105-106.

1918e Entschließung des Deutschen Volksrates in Gottschee; Gottscheer Bote, 19. oktobra, str. 153-154.

1918f Zur Beachtung; Gottscheer Bote, 4. novembra, str. 161.

1918 g Unverzagt; Gottscheer Bote, 19. novembra, str. 169.

1918h Eingabe der Gottscheer Gemeinden an die Narodna Vlada SHS; Gottscheer Bote, 4. decembra, str. 177.

1918i Kočevska pisma. 1. pismo; Slovenec, 10. decembra, str. 1.

1918j Kočevska pisma. 2. pismo; Slovenec, 13. decembra, str 2.

1918k Alldeutsch?; Gottscheer Bote, 19. decembra, str. 185-186.

19181 Kočevska pisma. 3. pismo; Slovenec, 23. decembra, str. 5-6.

1918m Kočevska pisma. 4; Slovenec, 28. decembra, str. 5. 
1919a Die Gottscheer und ihre slowenischen Nachbarn; I. Gottscheer Bote, 20. januarja, str. 17-18.

1919b Pismo iz Kočevja. 25. januarja 1919; Slovenec, 2. februarja, str. 6.

1919c Pismo iz Kočevja. 31. januarja 1919; Slovenec, 8. februarja, str. 2.

1919d Goldene worte Wilsons; Gottscheer Bote, 1. februarja, str. 25.

1919e Eidgenossenschaft »G'rad oder Un'grad «?; Fremden-Blatt, 12. marca, str. 1.

1919. Kočevarji hočejo svojo republiko!; Slovenec, 15. marca, str. 2.

1919g Gottschee; The New York Times, 18. marca, str. 10.

1920 Das große Hutdigungsfest in Laibach und die Deutschen; Gottscheer Zeitung, 1. julija, str. 55.

1921 Gottschee. Verbotene Bilder. Gottscheer Zeitung, 15. aprila, str. 29.

1922 Borovec. Kriegerdenkmal; Gottscheer Zeitung, 10. septembra, str. 139-140.

1926a Stara Cerkev. Heldendenkmal; Gottscheer Zeitung, 1. marca, str. 2.

1926b Stara Cerkev; Kriegerdenkmalweihe. Gottscheer Zeitung, 10. septembra, str. 3 .

1926c Die Enthüllung des Mitterdorfer Kriegerdenkmales; Gottscheer Zeitung, 20. septembra, str. 1-2.

1926d Kočevje. Spomenik padlim vojakom; Slovenec, 28. septembra, str. 5.

1926e Stara Cerkev. Für das Heldendenkmal; Gottscheer Zeitung, 20. decembra, str. 4.

1927a Ein Invalidentag in Mitterdorf; Gottscheer Zeitung, 10. oktobra, str. $1-2$.

1927b Heldenehrung; Gottscheer Zeitung, 10. oktobra, str. 2.

1927c Krieger-Gedenkblatt; Gottscheer Zeitung, 20. november, str. 4.

1927d Ehret die Helden!; Gottscheer Zeitung, 10. decembra, str. 2.

1928a Hinterberg. Das Gründungskomitee für ein Kriegerdenkmal; Gottscheer Zeitung, 1. maja, str. 6.

1928b Kotschen. Spendenausweis; Gottscheer Zeitung, 10. oktobra, str. 3.

1928c Ein Kriegergedenkstein; Gottscheer Zeitung, 20. oktobra, str. 8.

1928d Zehn Jahre Jugoslawien; Gottscheer Zeitung, 10. novembra, str. 1.

1934 Den Manen unseres großen verewigten Herrschers; Gottscheer Zeitung, 20. oktobra, str. 2-3.

2009 Kriegerdenkmal in Mitterdorf. Gottscheer Zeitung, september/oktober str. 18. 
2018a Jugoslovanski spomeniki, povezani s 1. svetovno vojno (1918-1941). Simpozij. Ljubljana, 18. in 19. oktober 2018. Ljubljana: Oddelek za umetnostno zgodovino Filozofske fakultete Univerze v Ljubljani.

2018b 53. Gottscheer Kulturwoche: vom 30. Juli bis 5. August 2018, Gottscheer Gedächtnisstätte Klagenfurt Schloß Krastowitz: Der Anfang vom Ende des Gottscheer Landes. Klagenfurt: Gottscheer Landsmannschaft in Klagenfurt.

2019 54. Gottscheer Kulturwoche: vom 29. Juli bis 4. August 2019, Gottscheer Gedächtnisstätte Klagenfurt Schloß Krastowitz: 1919 Schicksalshafte Veränderungen. Klagenfurt: Gottscheer Landsmannschaft in Klagenfurt.

Nora, Pierre 1989 Between Memory and History: Les Lieux de Mémoire; Representations, št. 26, str. 7-24.

PetSChAUer, ERICH 1984 »Das Jahrhunderbuch«: Gottschee and its people through the centuries. New York: Gottscheer Relief Association.

RUS, JožE 1939 Jedro kočevskega vprašanja; Janko Mačkovšek, ur. Kočevski zbornik: razprave o Kočevski in njenih ljudeh. str. 131-173, Ljubljana: Vodstvo Družbe sv. Cirila in Metoda.

Schröer, KARL Julius 1869 Ein Ausflug nach Gottschee. Beitrag der Erforschung der Gottscheer Mundart. Wien: K. K. Hof. und Staatsdrückerei.

Simonič, IVAn 1939 Zgodovina kočevskega ozemlja; ur. Janko Mačkovšek, ur. Kočevski zbornik: razprave o Kočevski in njenih ljudeh, str. 45-130, Ljubljana: Vodstvo Družbe sv. Cirila in Metoda.

1971 Zgodovina mesta Kočevje in Kočevske; Herman Kotar, Marija Andeselič in Miha Briški, ur. 500 let mesta Kočevje: 1471-1971, str. 5-52, Kočevje: Skupščina občine.

SVOLJŠAK, PETRA 1995 Neodvisna kočevska republika; Kronika, št. 3, str. 103-107.

ŠTEPEC, MARKo 2018 Spomeniki 1. svetovne vojne v Sloveniji; Jugoslovanski spomeniki, povezani s 1. svetovno vojno (1918-1941). Simpozij. Ljubljana, 18. in 19. oktober 2018. Ljubljana: Oddelek za umetnostno zgodovino Filozofske fakultete Univerze v Ljubljani.

TSCHINkel, Wilhelm 2004 Kočevarska folklora: v šegah, navadah, pravljicah, povedkah, legendah in drugih folklornih izročilih = Gottscheer Volkstum: in Sitte, Brauch, Märchen, Sagen, Legenden und anderen volkstümlichen Überlieferungen. Ljubljana: Založba ZRC, ZRC SAZU.

TномалоN, Вовві 2010 Memories of Gottsche: A narrated hitsory of fidelity and fragility. CreateSpace Independent Publishing Platform.

Trdan, Vanda 1996 Zabrisane sledi (zgodovina Kočevarjev od 1900 do 1918). Diplomska naloga. Univerza v Ljubljani, Filozofska fakulteta, Oddelek za zgodovino.

1999 Življenje kočevskih Nemcev med 1850 in 1918. Magistrska naloga. Univerza v Ljubljani, Filozofska fakulteta, Oddelek za zgodovino.

Vovko, ANDREJ 1986 Nemško manjšinsko šolstvo na Slovenskem v obdobju stare Jugoslavije; Zgodovinski časopis, št. 3, str. 311-321. 
WeISS, JANEZ 2010 Viniška republika. Zgodovina t. i. Viniške republike kot doprinos k razumevanju revolucionarnega leta 1919 na Dolenjskem in v Beli krajini; Rast: revija za literaturo, kulturo in družbena vprašanja, št. 1, str. 35-50.

ZAHRA, TARA 2008 Kidnapped souls: national indifference and the battle for children in the Bohemian Lands, 1900-1948. Ithaca: Cornell University Press.

ZORN, TONE 1974 Kulturna avtonomija za koroške Slovence in nemška manjšina v Sloveniji med obema vojnama; Zgodovinski časopis, št. 3-4, str. 347-366.

Zupan, Gojko, Mitja Ferenc in France M. Dolinar 1993 Cerkve na Koćevskem nekoč in danes. Kočevje: Muzej, Župnija.

Zupan, GojKo, In Mitja Ferenc 2013 Izgubljene kočevske vasi: nekoč so z nami živeli kočevski Nemci. Del 3: R-Ž. Ljubljana: Znanstvena založba Filozofske fakultete. 